\title{
Changing in chemical and physical attributes of a sandy soil under irrigated mango cultivation in semiarid region
}

\author{
José Alberto Ferreira Cardoso', Augusto Miguel Nascimento Lima ${ }^{2 *}$ \\ Tony Jarbas Ferreira Cunha ${ }^{3}$, Marcos Sales Rodrigues ${ }^{2}$, Luis Carlos Hernani, \\ 1 Federal University of São Francisco Valley, ,Juazeiro, Ba, Brazil. \\ 2 Federal University of São Francisco Valley, Petrolina,Pe, Brazil. \\ 3 Brazilian Agricultural Research Corporation, Petrolina, Pe, Brazil. \\ 4 Brazilian Agricultural Research Corporation, Rio de Janeiro, RJ, Brazil. \\ *Corresponding author, e-mail: augusto.lima@univasf.edu.br
} Jailson Cavalcante Cunha' ${ }^{1}$, Andre Julio do Amaral ${ }^{4}$, Manoel Batista de Oliveira Neto ${ }^{4}$

\begin{abstract}
Accelerated land use changes have been observed in Brazil. In Northeast, the Caatinga (native vegetation) has been replaced by fruit production, especially by mango and grapevine cultivation. Land use changes, tied to management techniques, can change the soil chemical and physical attributes. Thus, the present study aimed to evaluate the impact of irrigated mango cultivation in soil chemical and physical attributes in relation to the native Caatinga in the semiarid region. The study was carried out at Boa Esperança Farm located in Petrolina, Pernambuco State, Brazil. In areas under irrigated mango and native Caatinga soil samples at 0-10 and 10$20 \mathrm{~cm}$ depth were collected. After collected and prepared soil samples, it was determined the macro $\left(\mathrm{Ca}^{2+}, \mathrm{Mg}^{2+}, \mathrm{K}+\mathrm{P}\right)$ and micronutrients $\left(\mathrm{Cu}^{2+}, \mathrm{Fe}^{2+}, \mathrm{Zn}^{2+}, \mathrm{Mn}^{2+}\right)$ contents, Na content, electrical conductivity, $\mathrm{pH}$, exchangeable acidity $\left(\mathrm{Al}^{3+}\right)$ and potential acidity $(\mathrm{H}+\mathrm{Al})$. It was also determined soil texture, bulk density, particle density and total porosity. The mango cultivation increased the macronutrient contents, as well as, the micronutrients except for $\mathrm{Fe}^{2+}$ content. The physical attributes did not show difference comparing irrigated mango to native caatinga.
\end{abstract}

Keywords: bulk density, soil fertility, fruit plant, Psamment, Mangifera indica L.

\section{Introduction}

The semi-arid region has stood out in the national scenario as one of the main mango-producing regions, mainly due to the irrigated perimeters located in the Sub-medium São Francisco River Valley, generating foreign exchange by exporting fruits to the European Union and to the United States. In spite of the productive potential of the irrigated perimeters, Corrêa et al. (2010) state that the sustainability of these perimeters is conditioned to the maintenance of soil quality, since in agricultural areas chemical, physical and biological attributes can be modified by the application of fertilizers and pesticides, machines traffic, alteration of the water regime in the hydrographic basins, among others. Soils, when subjected to certain cropping systems, tend to be in a new state of equilibrium, reflected in changing of their properties, which may be unfavorable to the maintenance of productive capacity. A number of studies have been carried out to identify which soil attributes are changed by land-use (Müller et al., 2011, Dantes et al., 2012, Rodrigues et al., 2016), however, there are few studies comparing fruit cultivation areas with Caatinga areas (native vegetation) in the semi-arid region.

Among the soil chemical attributes that are influenced by the land-use and used as soil quality indicators are $\mathrm{pH}$, cation exchange 
capacity (CEC), soil electrical conductivity (EC). soil macro and micronutrients and soil organic matter (SOM) stocks (Assis et al., 2010).

According to Reynolds et al. (2002), soil physical quality is an important element of soil sustainability. In the northeast of Brazil (semiarid region), for example, the replacement of Caatinga by coconut crop has caused several degradations, reducing the physical quality of a sandy soil (Rodrigues et al., 2016). Soil tillage can promote considerable changes in soil physical attributes (Cunha et al., 2011; Deperon Júnior et al., 2016), which directly affects soil porosity and soil bulk density, which are used as indicators of soil physical quality. Additionally, the pedoclimatic characteristics of the semi-arid region, such as high evaporation rates, shallow and generally sandy soils may increase the risk of soil compaction and salt accumulation (Santos et al., 2012).

Despite the socioeconomic importance of the mango marketing in Brazil, especially in the Sub-medium São Francisco valley region, little is known about the influence that the substitution of the Caatinga by the irrigated mango crop can cause on the chemical and physical attributes in sandy soils which, according to Albuquerque et al. (2011), are considered low resilience and high intrinsic fragility, even when submitted to low management intensity.

Therefore, the present study aimed to evaluate the impact of an irrigated mango area on some chemical and physical attributes of a sandy soil in relation to a Caatinga area.

\section{Materials and Methods}

The study was carried out at Boa Esperança farm, Petrolina county, Pernambuco state, Brazil. The study area is located at the geographical coordinates latitude $9^{\circ} 19^{\prime} 55.8^{\prime \prime} \mathrm{S}$, longitude $40^{\circ} 26^{\prime} 54.2^{\prime \prime} \mathrm{W}$ and an average altitude of $373 \mathrm{~m}$. The climate of the region is BSwh (semiarid), according to the climatic classification of Köppen, with low rainfall (400 to $800 \mathrm{~mm}$ ). The annual average temperature of $26.3^{\circ} \mathrm{C}$, annual relative humidity of $71 \%$, solar radiation of $2774 \mathrm{~h}$, average evapotranspiration of $7.5 \mathrm{~mm} \mathrm{day}^{-1}$ and wind speed of $19.7 \mathrm{~km} \mathrm{day}^{-1}$. The soil of the study area was classified as a "Neossolo Quartzarênico órtico típico" (EMBRAPA, 2013) or Psamment (Soil Survey Staff 2014).

Soil samples were collected in November 2012, in two areas at Boa Esperança farm, one with irrigated mango (20 years old) and another one with Caatinga (Native vegetation), located approximately $150 \mathrm{~m}$ apart. Previously, the area with mango crop was occupied by Caatinga until the middle of 1993. After the removal of the Caatinga vegetation, the vegetal wastes were removed from the area and the soil was prepared (plowed and harrowed) in order to plant the mango seedlings. The soil acidity was corrected by applying limestone (Effective calcium carbonate equivalence (ECC): $85 \%$, $12 \% \mathrm{MgO}$ ). The mango trees (Tommy Atkins) was planted in the $5 \times 10-\mathrm{m}$ spacing. The bovine manure (20 L planting holes ${ }^{-1}$ ) and fertilization ( $P$, $K, S)$ were applied according to the soil analysis. Top-dressings with macronutrients $(N, K, S)$ and micronutrients $(B, Z n)$ were also performed to meet crop nutrient demand. Fertilizations were carried out through fertigation, taking in account the nutrient content determined in the soil analyzes performed after harvesting in each production cycle and according to the crop nutrient demand. In addition, $20 \mathrm{~L} \mathrm{plant}^{-1}$ of goat manure was applied in each production cycle.

The irrigation system used was microsprinkler (one emitter per plant), with a flow rate of $60 \mathrm{~L} \mathrm{~h}^{-1}$, in order to meet the water demand of the plant. Irrigation management was carried out based on crop evapotranspiration (ETc, mm), determined by the multiplication of the reference evapotranspiration (ETo, $\mathrm{mm}$ ) and the crop coefficient ( $\mathrm{kC}$ ) defined by Soares et al. (2006). The induction of plant flowering was performed by foliar applications (spraying) of calcium nitrate $(3.0 \%)$ and potassium nitrate $(1.5 \%)$ when observed in the field that the branches (buds) are in the full ripeness stage. The number of sprays varied according to the sprouting rate observed in the field at each production cycle.

The present work consisted of two treatments (irrigated mango and native Caatinga), with 10 replicates (10 georeferenced points). In the mango and the Caatinga fields, soil samples were collected at the layers of 0-10 and 10-20 cm depth. In the mango area, three simple 
samples were collected per georeferenced point to compose a composite sample under the planting row (in the canopy region) and in the Caatinga area, a simple sample was collected in the center of the georeferenced point and another two within a radius of $1 \mathrm{~m}$ from this point. The soil samples were air-dried, broken, homogenized and passed through a $2.0 \mathrm{~mm}$ mesh sieve. Undisturbed soil cores $15 \mathrm{~cm}$ height and diameter) were taken at the same soil layers.

The $\mathrm{pH}$ values $\left(\mathrm{H}_{2} \mathrm{O}\right)$, potential acidity $(\mathrm{H}+\mathrm{Al})$, exchangeable acidity $\left(\mathrm{Al}^{3+}\right)$, electrical conductivity obtained by saturated paste extract (EC), P content (extracted by Mehlich-1), $\mathrm{K}^{+}$, $\mathrm{Ca}^{2+}, \mathrm{Mg}^{2+}$, and $\mathrm{Na}^{+}$were determined using three replications and the averages were calculated. Micronutrient contents (extracted by Mehlich-1), $\mathrm{Cu}^{2+}, \mathrm{Fe}^{2+}, \mathrm{Mn}^{2+}$ and $\mathrm{Zn}^{2+}$ were also determined. All chemical analyzes were performed according to EMBRAPA (1997) and the results were expressed based on soil volume. Afterwards, the sum of basis (SB), cation exchange capacity (CEC), and percentage of soil base saturation (V) were calculated.

Regarding of soil physical analysis, soil texture, soil bulk density (BD), soil particle density (PD) and total porosity (TP) were determined according to EMBRAPA (1997).

The effects of mango cultivation on the soil chemical and physical attributes compared to the Caatinga area were assessed by performing descriptive analyzes to obtain the variance estimates and the results submitted to the comparison of means by the Student's t-test (at $5 \%$ of probability). It is important to highlight that the results of the soil chemical and physical analyzes did not take into account the variation in depth in the treatments, but among the treatments in each soil layer evaluated. All statistical analyses were performed using Sisvar 5.1 statistical software.

\section{Results and Discussion}

The soil under mango cultivation showed higher available macronutrient contents $(P$, $\mathrm{Ca}^{2+}, \mathrm{Mg}^{2+}, \mathrm{K}^{+}$) and $\mathrm{Na}^{+}$in comparison with the soil under native Caatinga at the layers of 0-10 and 10-20 cm depth (Figure 1). The contribution of nutrients by fertilization during the production cycles of the mango tree to meet the crop demand contributed to higher soil nutrient contents compared to the soil under Caatinga vegetation. In addition, the daily irrigation may have contributed to the increase of nutrients in the soil under mango crop compared to the soil under Caatinga. Amaral (2011) states that even using low-salinity water ( $E C<0.75 \mathrm{dS} \mathrm{m}^{-1}$ ), as is the case of São Francisco River water when applied in an annual volume of $20,000 \mathrm{~m}^{3} \mathrm{ha}^{-1}$ about 10 tons per year of salts can be added to the soil. The climatic conditions of the semi-arid region, such as the low rainfall rate, may also have favored lower losses of nutrients from leaching and, consequently, their accumulation in the soil.

Evaluating the chemical attributes of an "Argissolo Vermelho" (Ultisol) in a citrus orchard in Rio Grande do Sul state, Müller et al. (2011) observed an increase in the $\mathrm{P}, \mathrm{K}^{+}, \mathrm{Ca}^{2+}, \mathrm{Mg}^{2+}$ content and soil organic matter content at the layer of $0-40 \mathrm{~cm}$ depth in comparison with an adjacent native vegetation area.

The available soil $\mathrm{P}$ content under the mango field at the layer of $0-10 \mathrm{~cm}$ depth was classified as high (21.62 $\left.\mathrm{mg} \mathrm{dm}^{-3}\right)$, where as at the layer of $10-20 \mathrm{~cm}$ depth was classified as medium (12.92 $\mathrm{mg} \mathrm{dm}^{-3}$ ), according to Silva et al. (2002), for mango crop in the Sub-medium São Francisco Valley region. It is observed that the available $P$ content in the topsoil of the mango area was more than double in the soil under Caatinga (10.22 $\mathrm{mg} \mathrm{dm}^{-3}$ ) (Figure 1). This is due to the residual effect of phosphate fertilizers in the area and the low rates $P$ recovery by the mango crop, which favors the increase of soil fertility for this element over time. Only 10 to $30 \%$ of the P added to the soil by phosphate fertilization is recovered or used by the plants (Syers et al., 2008). Corrêa et al. (2009) also observed low P content in sandy soils under native vegetation in the Brazilian semiarid region, ranging from $4.1 \mathrm{mg} \mathrm{dm}^{-3}$ at the layer of $30-60 \mathrm{~cm}$ depth to $7.4 \mathrm{mg} \mathrm{dm}^{-3}$ at the layer of $0-10 \mathrm{~cm}$ depth.

In a study carried out in the Zona da Mata region (Minas Gerais State) evaluating the soil chemical attributes under orange, sugarcane, pasture and native forest, Portugal et al. (2010) observed that the highest available $P$ contents were found in the orange and 
sugarcane fields, whereas the forest and pasture showed the lowest values. The highest $P$ values in the soils under orange and sugarcane fields are expected, due to the use of phosphate fertilizers in these agricultural systems, in which there is a more technified agriculture, similarly to the condition of the present study.

The soil under mango field showed $\mathrm{Ca}^{2+}$ contents of $1.71 \mathrm{cmol}_{\mathrm{c}} \mathrm{dm}^{-3}$ and $0.94 \mathrm{cmol}_{\mathrm{c}} \mathrm{dm}^{-3}$, and $\mathrm{Mg}^{2+}$ of $0.96 \mathrm{cmol}_{\mathrm{c}} \mathrm{dm}^{-3}$ and $0.71 \mathrm{cmol}_{\mathrm{c}}$ $\mathrm{dm}^{-3}$ for the layers of $0-10$ and $10-20 \mathrm{~cm}$ depth, respectively, which were higher than those observed for the soil under native vegetation $\left(\mathrm{Ca}^{2+}=0,73 \mathrm{cmol}_{\mathrm{c}} \mathrm{dm}^{-3}\right.$ and $0,40 \mathrm{cmol}_{\mathrm{c}} \mathrm{dm}^{-3} ; \mathrm{Mg}^{2+}$ $=0,76 \mathrm{cmol}_{\mathrm{c}} \mathrm{dm}^{-3}$ and $0,64 \mathrm{cmol}_{\mathrm{c}} \mathrm{dm}^{-3}$ ) at the layers of 0-10 and 10-20 cm depth, respectively (Figure 1). Similar values of $\mathrm{Ca}^{2+}$ and $\mathrm{Mg}^{2+}$ were found by Oliveira et al. (2009) when studying
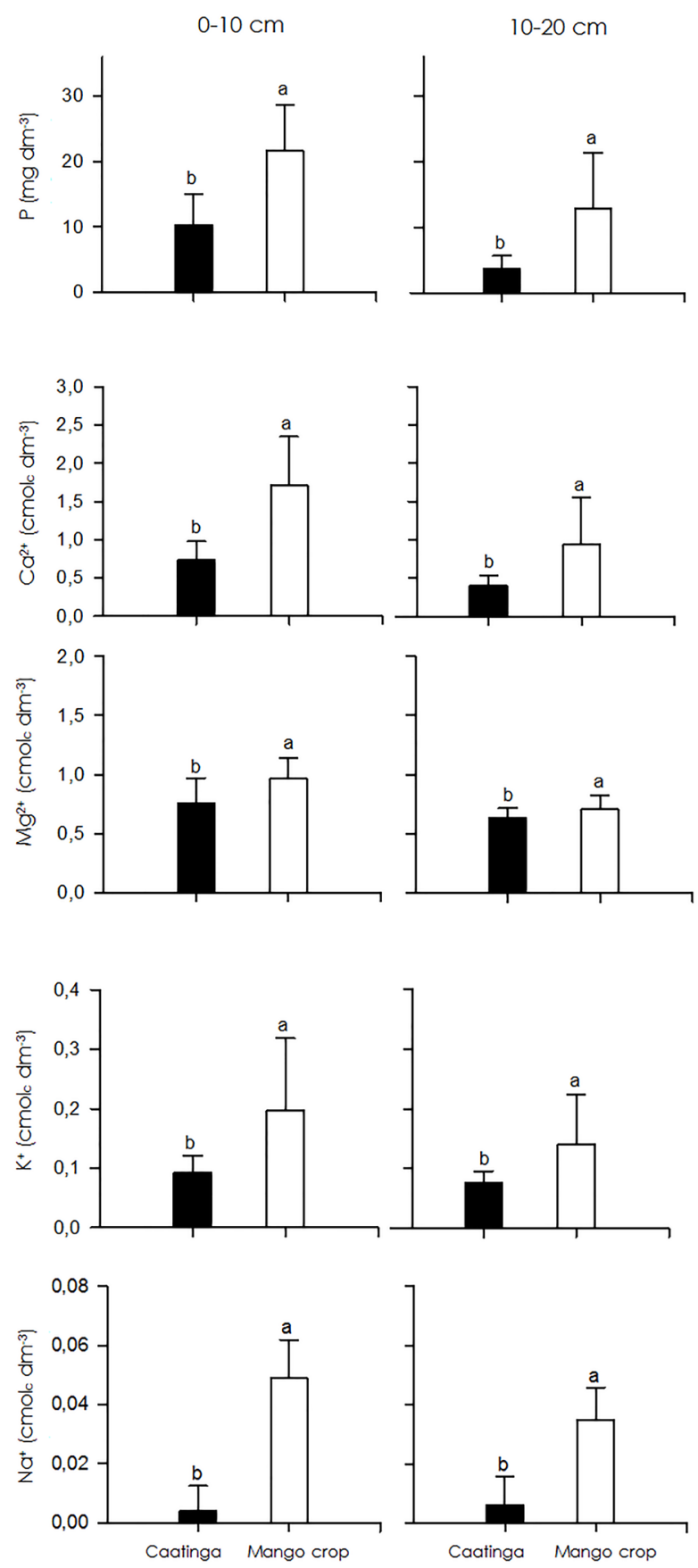

Figure 1. Soil $\mathrm{P}, \mathrm{Ca}^{2+}, \mathrm{Mg}^{2+}, \mathrm{K}^{+}$and $\mathrm{Na}^{+}$contents at the layer of $0-10$ and $10-20 \mathrm{~cm}$ depth under an irrigated mango field and Caatinga vegetation. Means followed by equal letters do not differ by Student's t-test ( $5 \%$ probability of error). Vertical bars represent the standard deviation of the mean. 
topossequences and their respective profiles in soils of the northeastern semi-arid region of Brazil. Evaluating soil chemical attributes under different land uses in irrigated perimeter of the semi-arid region, Pernambuco state, Corrêa et al. (2009) observed a considerable increase in $\mathrm{Ca}^{2+}$ and $\mathrm{Mg}^{2+}$ contents (short-cycle crops, fruit-crops, and pasture) in comparison to the Caatinga vegetation. Liming, often performed in mango cultivation, in addition to raising soil $\mathrm{pH}$, favors the precipitation of $\mathrm{Al}^{3+}$, provides $\mathrm{Ca}^{2+}$ and $\mathrm{Mg}^{2+}$ to the plants and, consequently, aids the development of the root system.

The $\mathrm{K}^{+}$content in the soil under the mango crop $10.20 \mathrm{cmol}_{\mathrm{c}} \mathrm{dm}^{-3}$ at the layer of $0-10$ $\mathrm{cm}$ depth and $0,14 \mathrm{cmol}_{\mathrm{c}} \mathrm{dm}^{-3}$ at the layer of 10$20 \mathrm{~cm}$ depth) were higher than the $\mathrm{K}^{+}$content under the Caatinga vegetation $10.09 \mathrm{cmol}_{\mathrm{c}} \mathrm{dm}^{-3}$ and $0.08 \mathrm{cmol}_{\mathrm{C}} \mathrm{dm}^{-3}$ for the layer of $0-10$ and $10-20$ $\mathrm{cm}$ depth, respectively) (Figure 1). The $\mathrm{K}^{+}$content in the soil under mango crop was classified as medium and low (Silva et al., 2002) at the layers of 0-10 and 10-20 cm depth, respectively.

The highest values of $\mathrm{Ca}^{2+}, \mathrm{Mg}^{2+}$, and $\mathrm{K}^{+}$in the soil under mango crop are due to the higher technological level adopted, such as soil correction and soil fertilization, replacing nutrients exported by the harvest and, or lost by leaching and erosion. In the Caatinga area, the low nutrient contents are explained in part by the fact that in this environment most of the nutrients are allocated to the vegetation, the low fertility of Psamment and the low nutrient cycling due to the climatic conditions of the semi-arid region.

The $\mathrm{Na}^{+}$content in the soil under the mango area and Caatinga vegetation ranged from 0.01 to $0.05 \mathrm{cmol}_{\mathrm{c}} \mathrm{dm}^{-3}$ (Figure 1). Therefore, the low $\mathrm{Na}^{+}$concentration does not limit agricultural production, which is a very important and beneficial condition for the management, since $\mathrm{Na}^{+}$can compromise plant growth, besides it can affect some soil physical properties, such as clay dispersion, which consequently affects hydraulic conductivity, infiltration, and aeration (Freire et al, 2003). No difference was observed in the electrical conductivity values (EC) of the soil comparing the mango area with the Caatinga area (Figure 2).

The lowest potential acidity $(\mathrm{H}+\mathrm{Al})$ values was verified for the mango area $0.86 \mathrm{cmol}_{\mathrm{c}} \mathrm{dm}^{-3}$ for the layer of $0-10$ and $10-20 \mathrm{~cm}$ depth) whereas the soil under the native vegetation showed the highest ones $\left(2.02 \mathrm{cmol}_{\mathrm{c}} \mathrm{dm}^{-3}\right.$ for the layer of 0-10 $\mathrm{cm}$ depth and $2.20 \mathrm{cmol}_{\mathrm{c}} \mathrm{dm}^{-3}$ for the layer of 10$20 \mathrm{~cm}$ depth) (Figure 2).

In a study evaluating the impact of sugarcane, pasture and orange trees in comparison with the native vegetation on some chemical attributes of a "Latossolo VermelhoAmarelo distrófico" (Oxisol) in Visconde do Rio Branco county, Zona da Mata region, Minas Gerais state, Portugal et al. (2010) observed that the potential acidity values were higher in the soil under native forest when compared to the agricultural crops. The authors argued that this occurred due to the higher organic matter content since soil organic matter has several functional groups, mainly the carboxylic and phenolic groups, which can deprotonate and then generate negative charges.

On the other hand, the soil under mango crop showed higher $\mathrm{pH}$ values (5.95 and 5.99) comparing to the soil under Caatinga (5.49 and 5.46) for the layers of $0-10$ and $10-20 \mathrm{~cm}$ depth, respectively ( Figure 2). Possibly, liming performed at each production cycle made it possible to raise the $\mathrm{pH}$ values and increase the availability of $\mathrm{Ca}^{2+}$ and $\mathrm{Mg}^{2+}$ in the soil under mango crop (Duarte et al., 2013). A similar result was observed by Corrêa et al. (2009), who studied sandy soils in the semiarid region and found higher $\mathrm{pH}$ values in a mango orchard when compared to the Caatinga area, due to the application of limestone at each production cycle.

The soil under mango crop showed the sum of basis ( $\mathrm{SB}=2.92$ and $1.82 \mathrm{cmol}_{\mathrm{c}} \mathrm{dm}^{-3}$ ) and base saturation ( $v=77.11 \%$ and $66.22 \%$ ) values higher than those found for the Caatinga area (SB: 1.59 and $1.12 \mathrm{cmol}_{\mathrm{c}} \mathrm{dm}^{-3}, \mathrm{~V}=46.78$ and $35.22 \%$ ), for the layers of 0-10 and $10-20 \mathrm{~cm}$ depth, respectively (Figure 2). The soil base saturation for the mango area was higher than 50\%, a condition attributed to the increase of exchangeable bases and reduction of potential acidity. However, it should be highlighted that even being classified as eutrophic, the soil under mango crop showed Iow CEC values, which reduces the soil capacity to retain nutrients. The addition of nutrients from 
$0-10 \mathrm{~cm} \quad 10-20 \mathrm{~cm}$
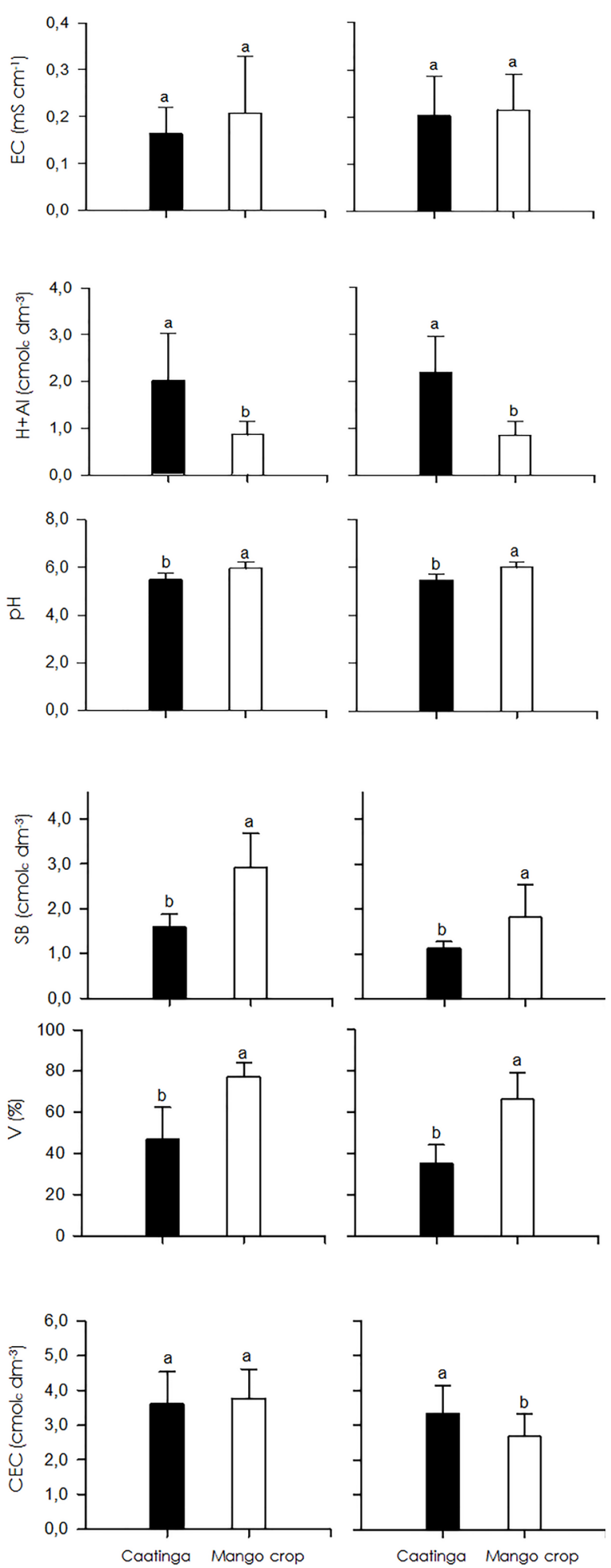

Figure 2. Electrical conductivity (EC), potential acidity (H+Al), pH, sum of basis (SB), percentage of soil base saturation (V) and cation exchange capacity (CEC) at the layer of $0-10$ and $10-20 \mathrm{~cm}$ depth under an irrigated mango field and Caatinga vegetation. Means followed by equal letters do not differ by Student's t-test ( $5 \%$ probability of error). Vertical bars represent the standard deviation of the mean. 
the fertilization contributed to the higher SB and $\checkmark$ values in the soil under mango crop. According to Corrêa et al. (2009), the substitution of native vegetation for agricultural crops results in higher values of the sum of basis and soil base saturation due to liming and fertilization. Similar results were observed by Portugal et al. (2010) when comparing soils under sugarcane fields, pastures and orange trees with native vegetation in the Zona da Mata region, who attributed this result to chemical fertilization in areas under agricultural crops.

The CEC values at the layer of $0-10 \mathrm{~cm}$ did not show a significant difference (Figure 2), whereas, at the layer of $10-20 \mathrm{~cm}$ depth, the soil under the mango crop area showed lower CEC value $\left(2.68 \mathrm{cmolc}^{-3}\right)$ than the soil under

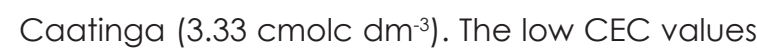
indicate that the soil has a small capacity to retain cations in exchangeable form. Thus, chemical fertilization must be fractioned in order to reduce nutrient losses by leaching (Mendes et. al, 2015). The low CEC values observed are due to the low clay content $(2.51 \%)$ which is expected for sandy soils as Psamment. The sand fraction, of non-colloidal nature, has a small specific surface, generating low $\mathrm{CEC}$ values.

The $\mathrm{Cu}^{2+}, \mathrm{Mn}^{2+}$ and $\mathrm{Zn}^{2+}$ contents at the layer of 0-10 cm depth were higher in the soil under the mango crop $\left(\mathrm{Cu}^{2+}=5,15 \mathrm{mg} \mathrm{dm}^{-3}\right.$, $\mathrm{Mn}^{2+}=17,77 \mathrm{mg} \mathrm{dm}^{-3}$ and $\mathrm{Zn}^{2+}=5,02 \mathrm{mg} \mathrm{dm}^{-3}$ ) than those found in the soil under Caatinga vegetation $\mathrm{CCu}^{2+}=1,90 \mathrm{mg} \mathrm{dm}{ }^{-3}, \mathrm{Mn}^{2+}=7,42$ $\mathrm{mg} \mathrm{dm}{ }^{-3}$ and $\mathrm{Zn}^{2+}=3,18 \mathrm{mg} \mathrm{dm}^{-3}$ ) (Figure 3). A similar result was observed for the $\mathrm{Mn}^{2+}$ content in the layer of $10-20 \mathrm{~cm}$ depth. The highest values of micronutrients found in the soil under mango crop are due to the technological level adopted in this agricultural system, which using fertilization with micronutrients, replacing the quantities exported by the harvest and/or lost by leaching and erosion. In the Caatinga area, the lower micronutrient contents are explained, in part, by the low natural fertility of the Psamment.

The $\mathrm{Fe}^{2+}$ contents $(16.44$ and $20.74 \mathrm{mg}$ $\mathrm{dm}^{-3}$ ) were lower in the soil under mango crop than those found in the soil under Caatinga $\left(21.90\right.$ and $\left.29.20 \mathrm{mg} \mathrm{dm}^{-3}\right)$ in the layers of $0-10$ and 10-20 cm depth, respectively (Figure 3). The lower $\mathrm{Fe}^{2+}$ content in the area under mango crop probably occurred because of the liming and, consequently, the pH values very close to 6.0, reducing the availability of this nutrient in the soil. Oliveira \& Nascimento (2006), studying several soil classes in Petrolina county, Pernambuco state, observed low Fe ${ }^{2+}$ content $\left(<0.05 \mathrm{mg} \mathrm{dm}^{-3}\right)$ in a Psamment under a hyperxerophytic Caatinga vegetation.

The mango crop did not promote statistically significant changes in soil bulk density values (Bd) (1.58 and $\left.1.56 \mathrm{~kg} \mathrm{dm}^{-3}\right), \mathrm{Pd}$ (2.49 and $2.52 \mathrm{~kg} \mathrm{dm}^{-3}$ ) and $\mathrm{Tp}$ (36.47 and 37.98\%) when compared to the soil under Caatinga ( $\mathrm{Bd}: 1.6$ and $1.65 \mathrm{~kg} \mathrm{dm}^{-3}$, Pd: 2.57 and $2.64 \mathrm{~kg} \mathrm{dm}^{-3}$; Tp: 36.28 and $37.63 \%$ ) in the layer of $0-10$ and $10-20$ $\mathrm{cm}$ depth, respectively (Figure 4).

The maintenance of plant waste on the soil surface under mango crop may have contributed to similar values of soil physical attributes compared to the soil under Caatinga vegetation. It should be highlighted that the application of fertilizers in the mango fields in the São Francisco Valley occurs through fertigation, which results in less traffic of agricultural machinery, preserving soil physical quality. The greatest limitation of this soil is the low capacity to retain water. However, several studies (Rocha et al., 2015, Xavier et al., 2012, Coelho et al., 2007) have been developed with the aim of making water management and fertilizer application more efficient, allowing Psamment soils, which occupies an expressive area in the semi-arid region, be cultivated satisfactorily with crops of high economic return.

It is expected that the particle density does not change due to the replacement of native vegetation by mango crop since this attribute is related to soil mineralogy. Agreeing with these results, Guareschi et al. (2012) did not find changes in the Pd values in different land use systems evaluated.

Although the present study has been developed in a sandy soil that, according to Albuquerque et al. (2011), are of low resilience and of high intrinsic fragility, the mango crop did not decrease the soil physical quality and increase the soil chemical quality. 

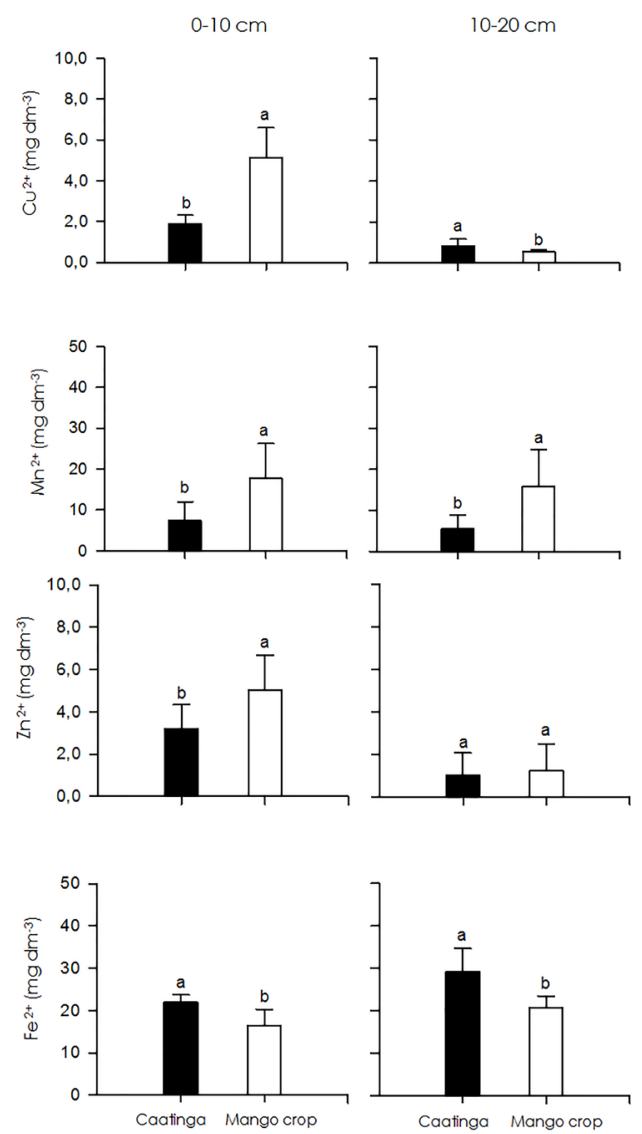

Figure 3. $\mathrm{Cu}^{2+}, \mathrm{Mn}^{2+}, \mathrm{Zn}^{2+}$ e $\mathrm{Fe}^{2+}$ contents at the layer of 0-10 and 10-20 cm depth under an irrigated mango field and Caatinga vegetation. Means followed by equal letters do not differ by Student's t-test (5\% probability of error). Vertical bars represent the standard deviation of the mean.

$0-10 \mathrm{~cm}$
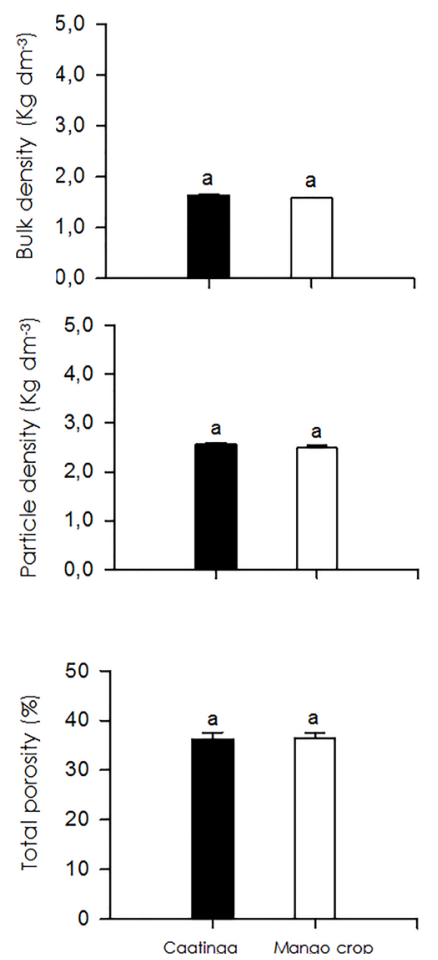

$10-20 \mathrm{~cm}$
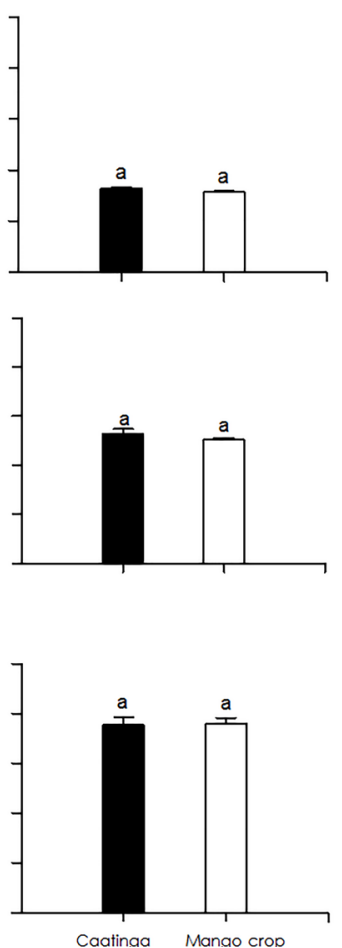

Figure 4. Soil bulk density, soil particle density, and total porosity at the layer of 0-10 and $10-20 \mathrm{~cm}$ depth under an irrigated mango field and Caatinga. Means followed by equal letters do not differ by Student's t-test ( $5 \%$ probability of error). Vertical bars represent the standard deviation of the mean. 


\section{Conclusions}

The cultivation of irrigated mango for 20 years positively affects the chemical attributes of a Psamment, mainly, increasing available of $P$, $\mathrm{K}^{+}, \mathrm{Ca}^{2+}$ and $\mathrm{Mg}^{2+}$ contents. On the other hand, soil physical attributes, such as bulk and particle density, and total porosity were not changed by the irrigated mango crop in a Psamment.

\section{References}

Amaral, F.C.S. 2011. Sistema brasileiro de classificação de terras para irrigação: enfoque na região semiárida. Embrapa Solos, Rio de Janeiro, Brasil. 164p.

Albuquerque, J.A., Almeida, J.A., Gatiboni, L.C., Eltz, F.L.F. 2011 . Atividades agrícolas de produção em solos frágeis no sul do Brasil. In: Klauberg Filho, O., Mafra, A.L., Gatiboni, L.C., (ed.) Tópicos em ciência do solo. Sociedade Brasileira de Ciência do Solo, Viçosa, Brasil. p.367-403.

Assis, C.P., Oliveira, T.S., Dantas, J.N., Mendonça, E.S. 2010. Organic matter and phosphorus fractions in irrigated agroecosystems in a semiarid region of Northeastern Brazil. Agriculture, Ecosystems \& Environment 138: 74-82.

Coelho, E.F., Santos, D.B., Azevedo, C.A.V. 2007. Sensor placement for soil water monitoring in lemon irrigated by micro sprinkler. Revista Brasileira de Engenharia Agrícola e Ambiental 11: 46-52.

Corrêa, R.M., Freire, M.B.G. dos S., Ferreira, R.L.C., Freire, F.J., Pessoa, L.G.M., Miranda, M.A., Melo, D.V.M. 2009. Atributos químicos de solos sob diferentes usos em perímetro irrigado no semiárido de Pernambuco. Revista Brasileira de Ciência do Solo 33: 305-314.

Corrêa, R.M., Freire, M.B.G.S., Ferreira, R.L.C., Silva, J.A.A., Pessoa, L.G.M., Miranda, M.A., Melo, D.V.M. 2010. Atributos físicos de solos sob diferentes usos com irrigação no semiárido de Pernambuco. Revista Brasileira de Engenhaira Agrícola e Ambental 14: 358-365.

Cunha, E.Q., Stone, L.F., Moreira, J.A.A., Ferreira, E.P.B., Didonet, A.D., Leandro, W.M. 2011 . Sistemas de preparo do solo e culturas de cobertura na produção orgânica de feijão e milho: I - atributos físicos do solo. Revista Brasileira de Ciência do Solo 35: 589-602.

Dantas, J.D.N., Oliveira, T.S., Mendonça, E.S., Assis, C.P. 2012. Qualidade de solo sob diferentes usos e manejos no Perímetro Irrigado Jaguaribe/ Apodi, CE. Revista Brasileira de Engenharia Agrícola e Ambiental, 16(1):18-26.
Deperon Júnior, M.A., Nagahama, H. de J., Olszevski, N., Cortez, J.W., Souza, E.B. 2016. Tillage machinery and compaction level influence on soil physical properties and corn agronomic aspects. Engenharia Agrícola 36: 367-376.

Duarte, A.S., Rolim, M.M., Silva, Ê.F.F.E., Pedrosa, E.M.R., Albuquerque, F.S., Magalhães, A.G. 2013. Alterações dos atributos físicos e químicos de um neossolo após aplicação de doses de manipueira. Revista Brasileira de Engenhaira Agrícola e Ambental 17: 938-946.

Empresa Brasileira de Pesquisa Agropecuária EMBRAPA. 1997. Manual de métodos de análise de solo. Centro Nacional de Pesquisa de Solos, Rio de Janeiro, Brasil. 212 p.

Empresa Brasileira de Pesquisa Agropecuária - EMBRAPA. 2013. Sistema brasileiro de classificação de solos. Centro Nacional de Pesquisa de Solos, Brasília, Brasil. 306 p.

Freire, M.B.G.S., Ruiz, H.A., Ribeiro, M.R., Ferreira, P.A., Alvarez V., V.H, Freire, F.J. 2003. Condutividade hidráulica de solos de Pernambuco em resposta à condutividade elétrica e RAS da água de irrigação. Revista Brasileira de Engenharia Agrícola e Ambiental 7: 45-52.

Guareschi, R.F, Pereira, M.G., Perin, A. 2012. Deposição de resíduos vegetais, matéria orgânica leve, estoques de carbono e nitrogênio e fósforo remanescente sob diferentes sistemas de manejo no cerrado goiano. Revista Brasileira de Ciência do Solo 36: 909-920.

Mendes, W.C., Alves Júnior, J., Cunha, P.C.R., Silva, A.R., Evangelista, A.W.P., Casaroli, D. 2015. Lixiviação de nitrato em função de lâminas de irrigação em solos argiloso e arenoso. Irriga 1: 47:56.

Müller, J., Levien, R., Trein, C.R., Sequinatto, L., Mazurana, M., Stürmer, S.L.K., Pietrzacka, R. 2011 . Atributos físicos e químicos de um Argissolo Vermelho, em pomar orgânico de citros com manejo da vegetação nas entrelinhas. Revista Brasileira de Fruticultura 33: 1127-1134.

Oliveira, A., Nascimento, C.W.A. 2006. Formas de manganês e ferro em solos de referência de Pernambuco. Revista Brasileira de Ciência do Solo 30: 99-110.

Oliveira, L.B., Fontes, M.P.F., Ribeiro, M.R., Ker, J.C. 2009. Morfologia e classificação de luvissolos e planossolos desenvolvidos de rochas metamórficas no semiárido do nordeste brasileiro. Revista Brasileira de Ciência do Solo 33: 1333-1345.

Portugal, A.F., Costa, O., Del'arco V., Costa, L.M. 2010. Propriedades físicas e químicas do solo em 
áreas com sistemas produtivos e mata na região da zona da mata mineira. Revista Brasileira de Ciência do Solo 34: 575-585.

Reynolds, W.D., Bowman, B.T., Drury, C.F., Tan, C.S., LU, X. 2002. Indicators of good physical quality: density and storage parameters. Geoderma, 110: 131-146.

Rocha, M.G., Bassoi, L.H., Silva, D.J. 2015. Atributos do solo, produção da videira 'syrah' irrigada e composição do mosto em função da adubação orgânica e nitrogenada. Revista Brasileira de Fruticultura 37: 220-229.

Rodrigues, M.S., Souza, C., Lima, D.D., Silva, S.D.P., Alves, D.C., Machado, N.S. 2016. Impacto do cultivo do coqueiro irrigado na qualidade física do solo na região semiárida brasileira. Ciencia del Suelo 34(1):139-144.

Santos, K.S., Montenegro, A.A., Almeida, B., Montenegro, S., Andrade, T.D.S., Fontes Júnior, R. 2012. Variabilidade espacial de atributos físicos em solos de vale aluvial no semiárido de Pernambuco. Revista Brasileira de Engenhaira Agrícola e Ambental 16: 828-835.

Silva, D.J., Quaggio, J.A., Pinto, A.P.C., Pinto, A.C.Q., Magalhães, A.F.J. 2002. Nutrição e adubação. In: Genú, P.J.C., Pinto, A.C.Q., (ed.) A cultura da mangueira. Embrapa Informação Tecnológica, Brasília, Brasil. p. 192-221.

Soares, J.M., Costa, F.F., Nascimento, T. 2006. Recomendações básicas para o manejo de água em fruteiras. Embrapa Semiárido, Petrolina, Brasil. 28p.

Souza Braz, A.M., Fernandes, A.R., Alleoni, L.R.F. 2013. Soil attributes after the conversion from forest to pasture in amazon. Land Degradantion and Development 24: 33-38.

Soil Survey Staff. Keys to soil taxonomy (2014) 12th edn. United States Department of Agriculture, Natural Resources Conservation Service, Washington, DC.

Syers, J.K., Johnston, A.E., Curtin, D. 2008. Efficiency of soil and fertilizer phosphorus: reconciling changing concepts of soil phosphorus behaviour with agronomic information. Rome: FAO. (Fertilizer and Plant Nutrition Bulletin, 18).

Xavier, F.A.S., Tavares, R.C., Marques, G.V., Rodrigues, F.M., Oliveira, T.S. 2012. Efeitos da irrigação localizada na granulometria e em atributos químicos de um Neossolo Quartzarênico cultivado com coqueiro anão. Revista Ciência Agronômica 43: 55-63. 